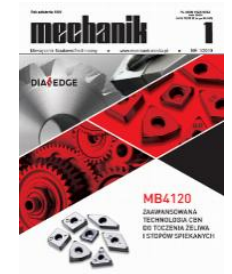

How to cite this article:

Authors: Robert Frączek, Marek Pałdyna, Krzysztof Miszczak, Witold Orzechowski, Łukasz Kawałek, Daniel B. Nycz Title of article: „Modernization of the head structure of the ED72 electrical train unit”

Mechanik, No. 1 (2019)

DOI: https://doi.org/10.17814/mechanik.2019.1.12

\title{
Modernization of the head structure of the ED72 electrical train unit
}

\author{
ROBERT FRĄCZEK \\ MAREK PALDYNA \\ KRZYSZTOF MISZCZAK \\ WITOLD ORZECHOWSKI \\ ŁUKASZ KAWAŁEK \\ DANIEL B. NYCZ *
}

\begin{abstract}
Mgr inż. Robert Frączek, r.frączek@zntkmm.pl - ZNTK Mińsk Mazowiecki S.A., Mińsk Mazowiecki, Polska Mgr inż. Marek Pałdyna, m.paldyna@zntkmm.pl - ZNTK Mińsk Mazowiecki S.A., Mińsk Mazowiecki, Polska Mgr inż. Krzysztof Miszczak, kmiszczak@cad.desart.com.pl - DES ART Sp. z o.o., Gdynia, Polska Mgr inż. Witold Orzechowski, worzechowski@cad.desart.com.pl - DES ART Sp. z o.o., Gdynia, Polska Mgr inż. Łukasz Kawałek, lkawalek@cad.desart.com.pl - DES ART Sp. z o.o., Gdynia, Polska Dr inż. Daniel B. Nycz, dnycz@cad.desart.com.pl, https://orcid.org/0000-0002-2756-8814 - DES ART Sp. z o.o., Gdynia, Polska,
\end{abstract}

The ED72 is an electrical train unit consisting of four wagons (two steering and two motor). The paper presents the modernization of the ED72 head structure focusing on numerical calculations including static, crash and fatigue strength calculations.

KEYWORDS: EZT ED72, modernization of the head structure, numerical strength calculations

\section{Introduction}

ED72 is a long-distance electrical train unit (EZT) manufactured at the Pafawag State Wagon Factory. Its construction was based on the EZT EN57 rail vehicle $[1,2]$.

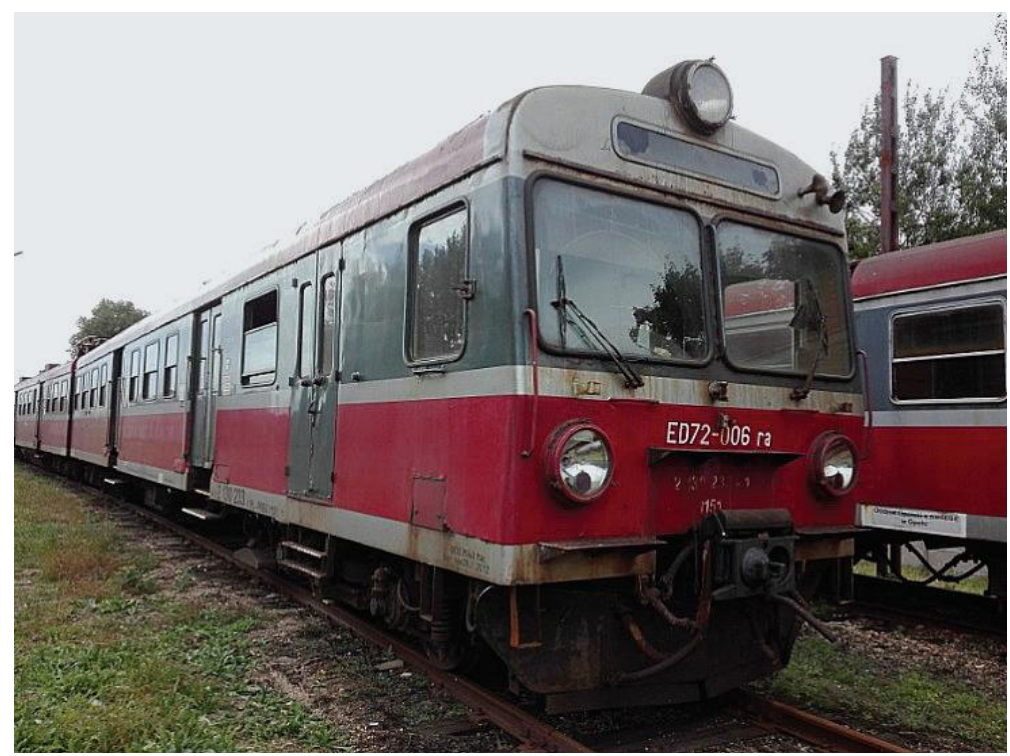

Fig. 1. EZT ED72-006 at ZNTK Minsk Mazowiecki 
The ED72 includes two distribution/control end wagons (factory designation - 5Bs; PKP designation - ra and $\mathrm{rb}$ ) and two middle engine wagons (factory designation - 6Bs; designation PKP - sa and sb) $[1,2]$.

Total length of the unit is $86.84 \mathrm{~m}$ with a total weight of 182 tons. The maximum speed of the unit is 110 $\mathrm{km} / \mathrm{h}$. Total number of seats -800 , including $235 / 232$ seating seats $[1,2]$.

The purpose of the work was to modernize the structure of the head of the ED72 traction unit, taking into account the requirements for static, crash and fatigue strength. The assumption was to make the head structure from S355 structural steel profiles and sheets (density $\rho=7850 \mathrm{~kg} / \mathrm{m}^{3}$, Young modulus $E=210 \mathrm{GPa}$, Poisson ratio $v=0.3$, yield strength $R e=355 \mathrm{MPa}$ and ultimate strength $R m=520 \mathrm{MPa}$ ).

Design works were done in SolidWorks 2014 software. Altair HyperWorks 2017 and FATEVAS environments were used for numerical calculations.

\section{Static strength calculations}

Static strength calculations were done based on PN-EN 12663-1: 2010 standard [3]. In standard [3], rail vehicles are classified into three groups divided into categories according to the design requirements for vehicle bodies. EZT ED72 belongs to category P-II. Static strength calculations required for this vehicle category include [3]:

- longitudinal static loads acting on the body,

- vertical static loads acting on the body,

- superposition of longitudinal and vertical static loads,

- test load cases for equipment fasteners.

Fig. 2 presents contour plot of von Mises equivalent stress, corresponding to the maximum values of all considered static load cases (envelope function).

According to the standard [3], if the design is verified only based on calculations, the value of the safety factor for the yield or $0.2 \%$ proof strength should be 1.15 . For S355 structural steel, the allowable stress value is $309 \mathrm{MPa}$.

The highest obtained value of equivalent stress - 301.7 MPa (fig. 2) - corresponds to compression load of $400 \mathrm{kN}$ acting on the buffer beam $150 \mathrm{~mm}$ above the floor plane. This value is $97.6 \%$ of allowable stress.

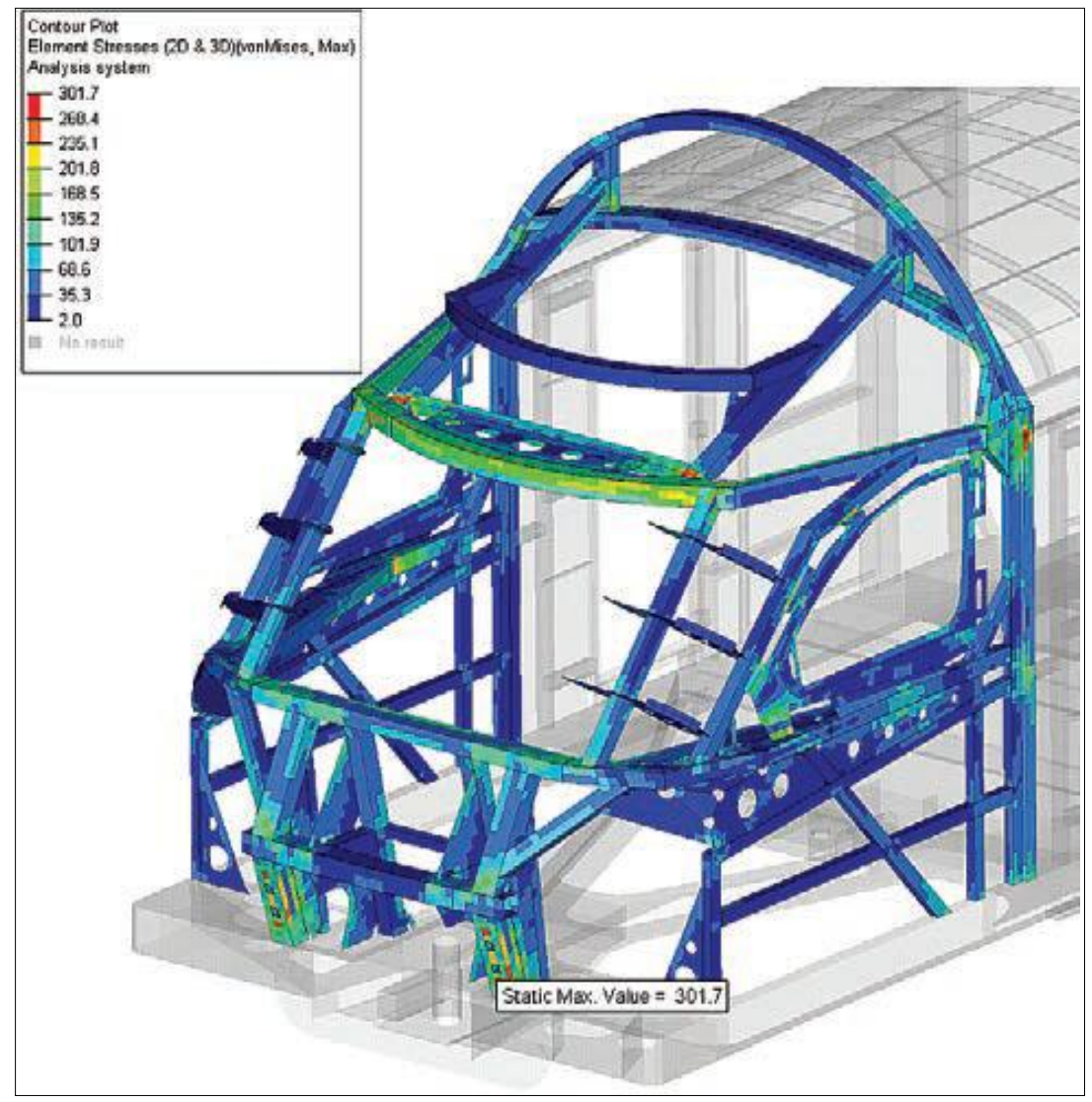

Fig. 2. Contour plot of von Mises equivalent stress corresponding to the maximum values of all considered static load cases [in MPa] 


\section{Crash strength calculations}

Crash strength calculations were done based on PN-EN 15227: 2008 standard [4]. The standard specifies requirements and measures regarding to the passive safety to protect rail vehicles against collisions and specifies properties that meet these requirements.

In standard [4], rail vehicles are classified into four categories. EZT ED72 belongs to category C-I. Three collision scenarios are required for this vehicle category [4]:

- collision with an identical train unit - collision speed of $36 \mathrm{~km} / \mathrm{h}$,

- collision with a rigid 80 ton obstacle with bumpers - collision speed of $36 \mathrm{~km} / \mathrm{h}$,

- collision with a large deformable obstacle (LDO) of mass of 15 tons.

For head structure assessment, the criteria given in the standard [4] were used, in particular not exceeding by the components of the head structure and the control panel the space around the driver's seat (survival space).

This study focuses on the collision with LDO, due to the largest impact of this scenario on the construction of the head structure.

Geometry of the large deformable obstacle is shown in fig. 3. LDO must have a mass of 15 tons and a center of mass at $1750 \mathrm{~mm}$ above rail level [4]. It should also have uniform density and stiffness in the axial direction and stiffness in the direction of impact adjusted to the stiffness specified by the standard (red curve in fig. 4) [4].

Adjustment to the standard characteristic should be obtained during the test of impact against LDO with a rigid sphere with a diameter of $3 \mathrm{~m}$, weight of 50 tons and initial speed of $30 \mathrm{~m} / \mathrm{s}$ [4]. The more obtained characteristic is closer to the standard characteristic, the better results can be expected using an obstacle in numerical simulations, therefore the standard curve is the minimum characteristic $[4,6]$

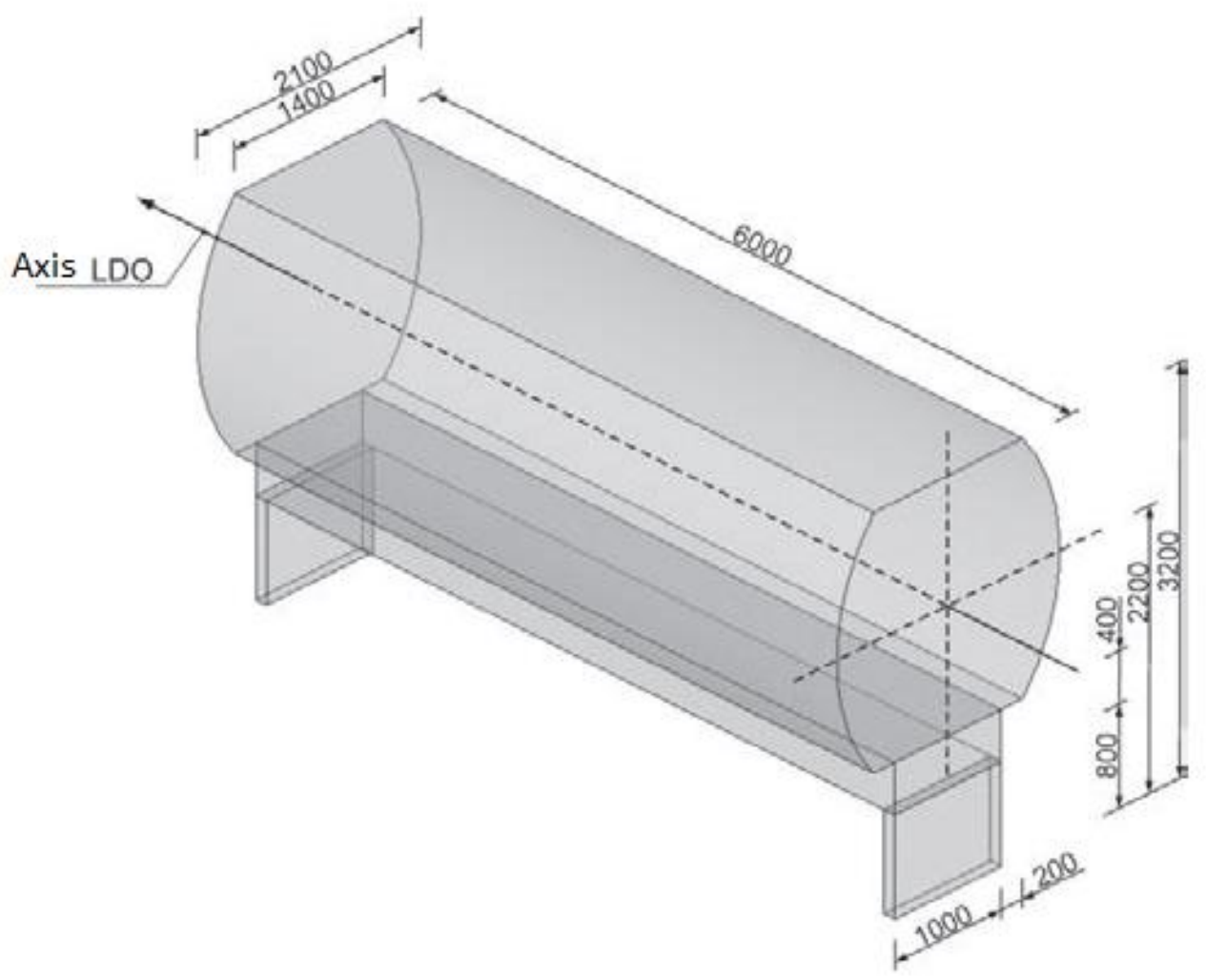

Fig. 3. Geometry of large deformable obstacle - LDO [4]

Fig. 4 shows a comparison of the stiffness obtained for the LDO numerical model with the standard characteristics.

The first numerical calculations of the collision of the modernized EZT ED72 with the LDO showed the need for additional reinforcements of the head structure due to its large deformation (fig. $5 a$ ), which mainly exceeds the survival space around the driver.

Changes made in the head structure (fig. 6) allowed for a significant reduction of this deformation (fig. $5 b$ ). 


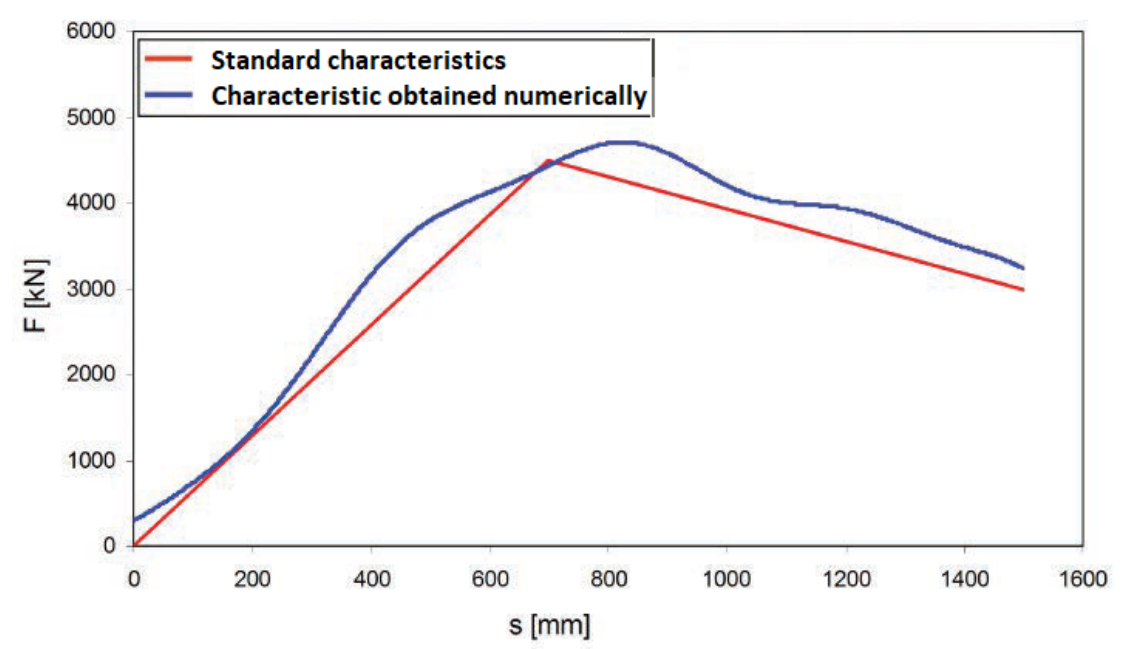

Fig. 4. Adjusting the LDO model stiffness characteristic to standard characteristic [4]

a)

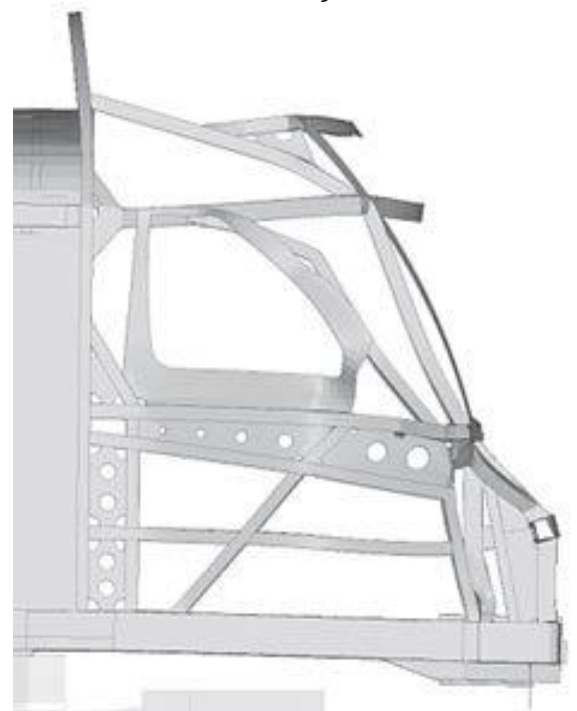

b)

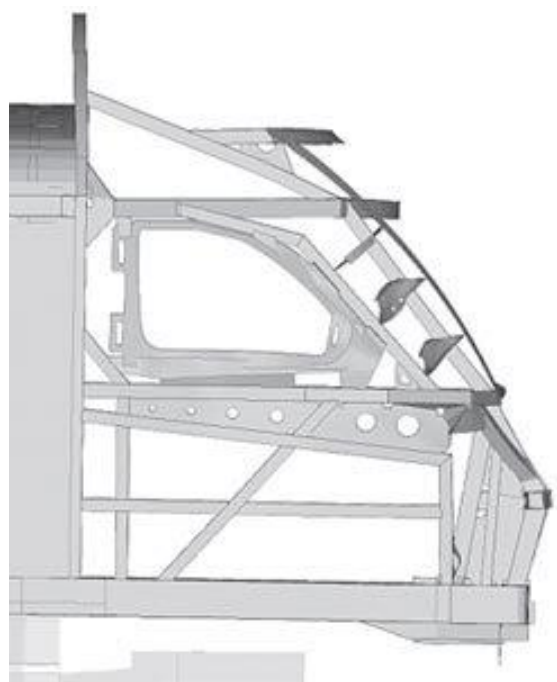

Fig. 5. Final deformation of the modernized construction of the EZT ED72 head structure during a collision with LDO: $a$ ) before strengthening of the structure, $b$ ) after strengthening of the structure

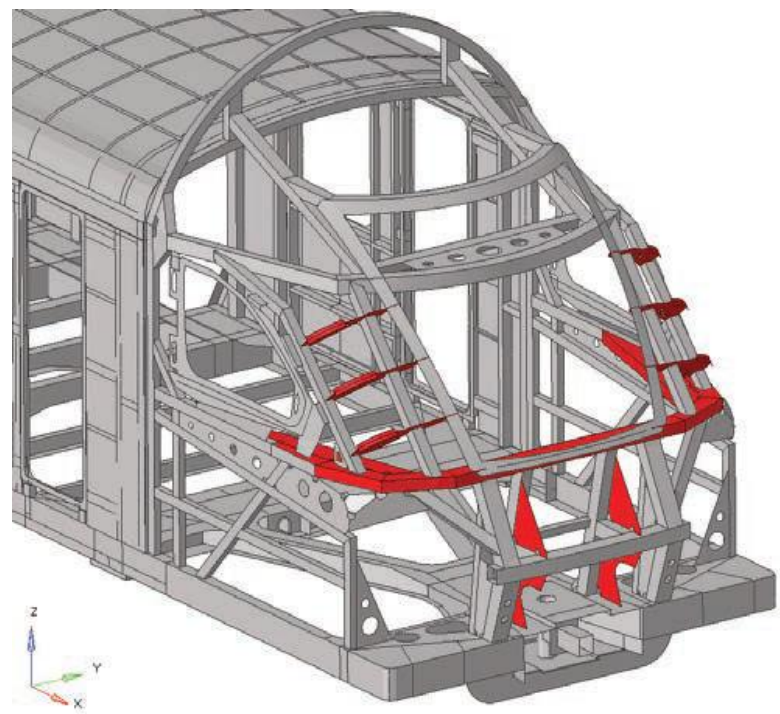

Fig. 6. Main areas of changes in the design of the EZT ED72 head structure, necessary to meet the requirements of the LDO collision scenario 


\section{Fatigue strength calculations}

Fatigue strength calculations were done based on PN-EN 12663-1: 2010 and DVS1612: 2009 standards [3, 5]. In the calculations according to [5], the ratio of resultant stress to allowable stress has been specified as the degree of use of allowable stress $U F$ (utilization factor). For the required number of $2.0 \mathrm{E}+06$ cycles and a $99.5 \%$ survival probability, the $U F$ should not exceed 1.0. For the base material, the AB curve (material subjected to heat treatment) from the MKJ diagram for S235/S355 steel [5] was used.

A combination of five load cases was considered in the calculations, taking into account loads from mass of passengers and accelerations due to the operation of the vehicle [3]. Fatigue strength calculations were performed for base material and welds of the head structure.

Fig. 7 shows the $U F$ contour plot for welds of the modernized EZT ED72 head structure. The maximum $U F$ value for welds is 0.96 . The maximum $U F$ value of 0.36 was obtained for base material.

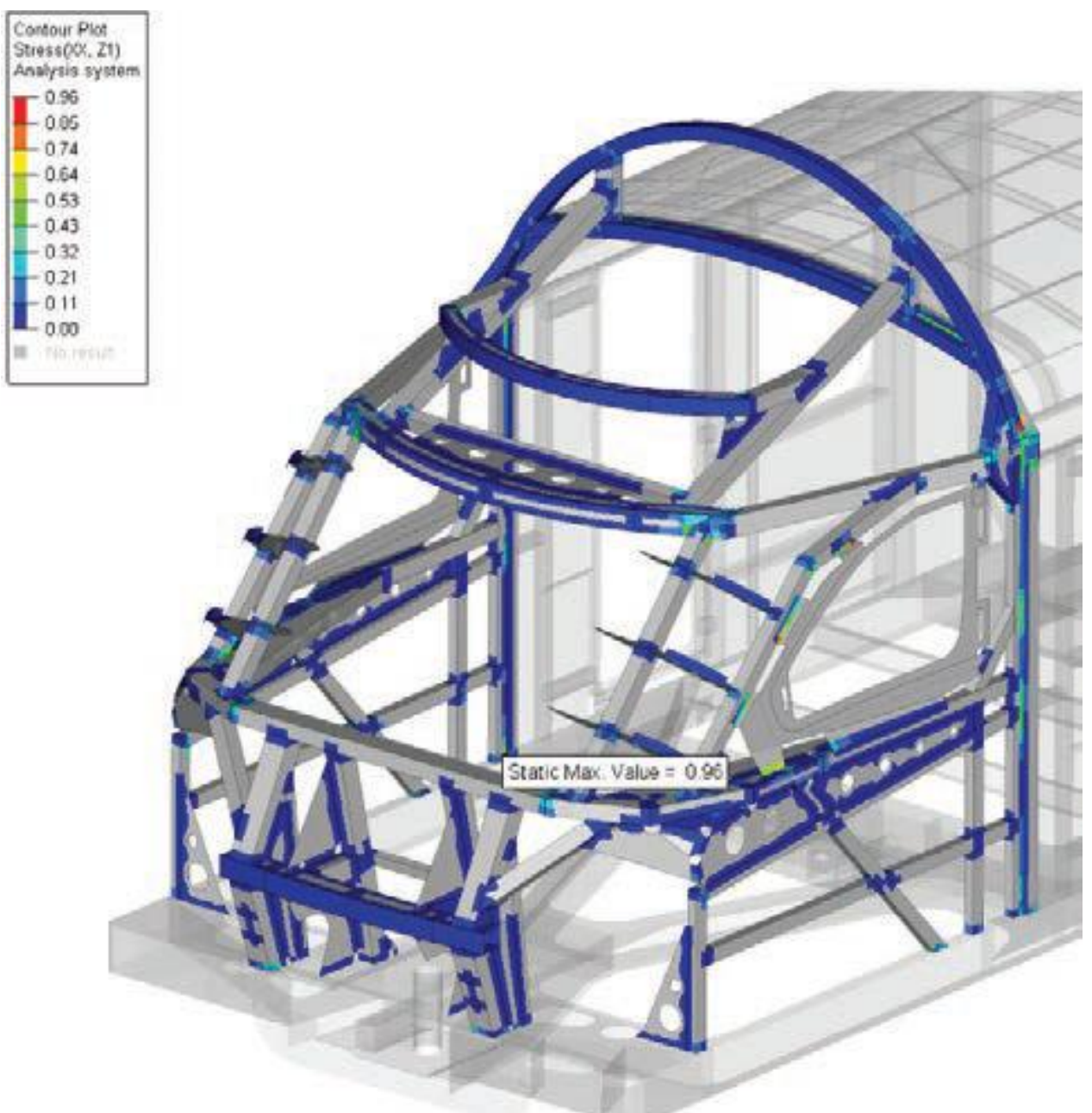

Fig. 7. Contour plot of utilization factor of welds

\section{Summary}

- The subject of the work is the modernization of the EZT ED72 head structure including the requirements of static, crash and fatigue strength.

- Static strength calculations include load cases of vehicle compression/tension, critical mass of passengers, vehicle lifting and test loads for equipment fastenings [3].

- Crash strength calculations cover three collision scenarios [4].

- Fatigue strength calculations were carried out for the base material and welds of the ED72 train unit head structure $[3,5]$.

- SolidWorks 2014 software was used for construction works. Altair HyperWorks 2017 and FATEVAS environments were used for numerical calculations. 
- The modernized structure of the EZT ED72 head fulfill all the requirements in terms of static, crash and fatigue strength.

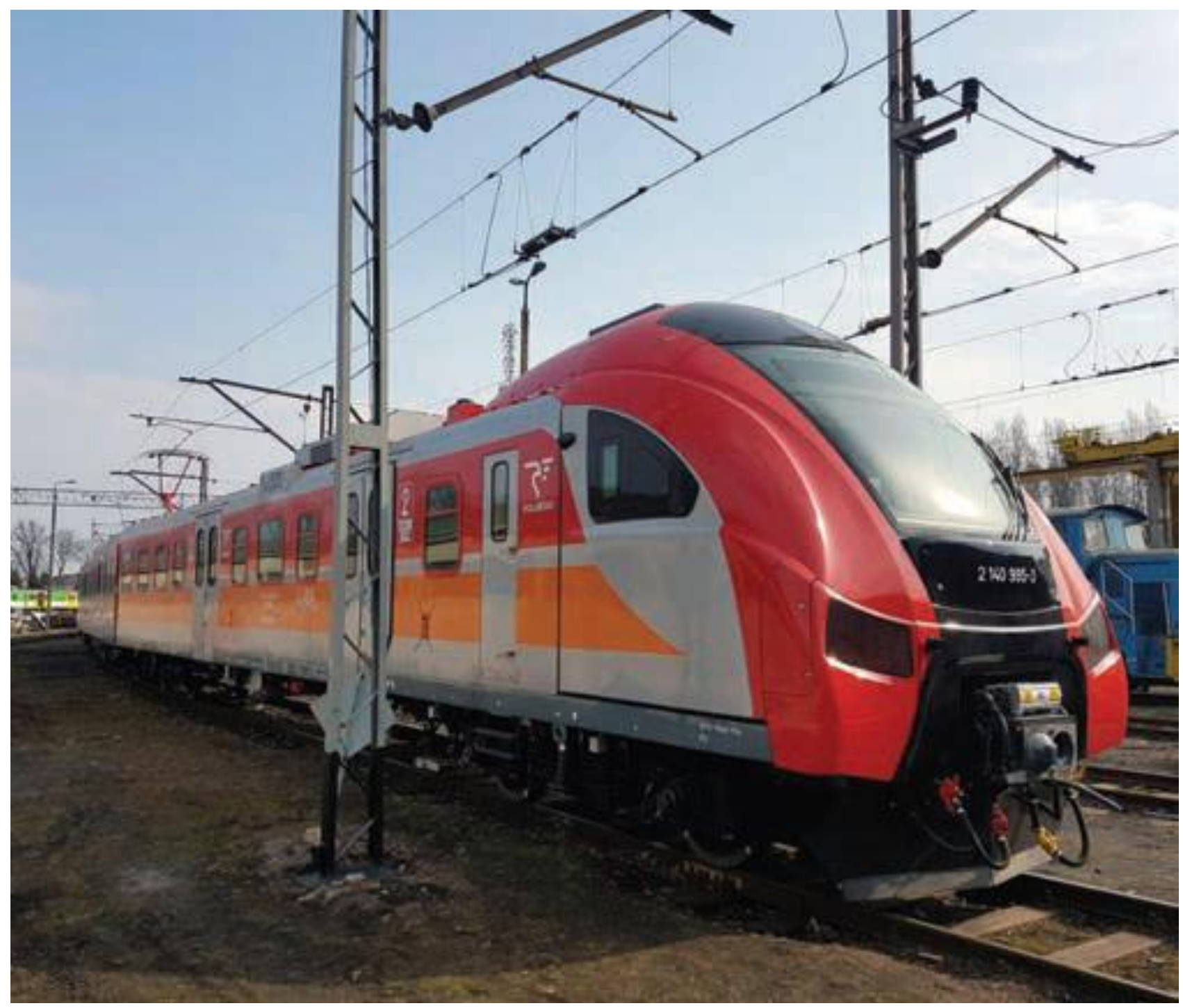

Fig. 8. EZT ED72 head structure after modernization in ZNTK Mińsk Mazowiecki

\section{REFERENCES}

[1] Terczyński P. „Elektryczne zespoły trakcyjne w Polsce - stan obecny i bliska perspektywa”. Technika Transportu Szynowego. 5-6 (2010): 13-20.

[2] Terczyński P. „Elektryczny zespół trakcyjny serii ED72”. Świat Kolei. 8 (2001): 37.

[3] PN-EN 12663-1:2010. Kolejnictwo - Wymagania konstrukcyjno-wytrzymałościowe dotyczące pudeł kolejowych pojazdów szynowych - Część 1: Lokomotywy i tabor pasażerski (i metoda alternatywna dla wagonów towarowych).

[4] PN-EN 15227:2008. Kolejnictwo - Wymagania zderzeniowe dla pudeł pojazdów szynowych.

[5] DVS1612:2009. Design and endurance strength assessment of welded joints with steels in rail vehicle construction.

[6] Spirk S., Kemka V., Kepka M., Malkovsky Z. „Design of a large deformable obstacle for railway crash simulations according to the applicable standard". Applied and Computational Mechanics. 6 (2012): 83-92. 